\title{
Effects Of Product Quality, Price, And Brand Image On The Buying Decision Of City Car Product
}

\author{
Amron Amron \\ Faculty of Economics and Business, \\ Dian Nuswantoro University, Semarang, Indonesia
}

\begin{abstract}
The study examined the effect of product quality, price, and brand image on buying decision of city car product in Semarang, Indonesia. The primary data was obtained from 100 respondents who had city cars. Surprisingly, from the three independent variables, it was found that the variable of product quality had greater effect compared with those of price and brand image. In other hand, the one with the smallest effect on buying decision was brand image. The study recommends the managements of city car companies to pay attention to the elements of product quality, price and brand in preparing their promotional programs in order to attract more consumers to buy city cars.
\end{abstract}

Keywords: City Car, Product Quality, Price, Brand Image, Buying Decision

\section{INTRODUCTION}

City car is a car designed in a small size because it is used in cities (Seizure, 2016). The type of car is designed for agile and comfortable driving in a city with dense traffic, easy to find a place for parking, and relatively economical fuel consumption (Seizure, 2016). The competition of city car is currently dominated by Japanese mobile brands, such as Honda, Toyota, and Daihatsu. For Asian region, particularly Southeast Asia, the production of cars of Honda and Toyota has a strong market share (Seizure, 2016). Similarly, in Indonesia, the population is over 200 million with high density concentrated in big cities in Java island, such as Semarang, so the public interest to buy city car is very high.

Based on the top brand index (TBI) in 2016, the most wanted city car brand in Indonesia was Honda Jazz (Topbrand, 2016). Top brand index is an award given to the best brands of consumer choice. It is based on the results of the research on consumers who put the best brand choice based on consumer choice. The higher the top brand index, the higher the consumers' choice to buy the brand (Topbrand, 2016). In 2016, The top brand index of Honda Jazz reached 22.5\%, followed by Toyota Agya at $12.7 \%$, and Toyota Yaris by $9.7 \%$. Furthermore, in 2017, Honda Jazz was still the most demanded brand by the percentage of $24 \%$, while Toyota Yaris was in the second order with $10.6 \%$, and the third position was Toyota Agya at 9.2\% (Topbrand, 2016). Based on the data, it can be concluded that city cars with the brand of Honda and Toyota were able to dominate the sales of city cars in Indonesia, whereas many other brands that sold city cars with the design and price which were not inferior to both brands. For example, the city car with the brand of City car, even with the price, design and feature which are not inferior to Toyota Agya, apparently ranked lower. For the reason, it is necessary to examine the factors that influence consumers in deciding to buy city cars in Semarang, Indonesia.

Buying decision is a decision made by individuals due to the stimuli from both external and internal matters existing in the individuals (Monroe, 2002; Amron, 2017). Consumers make many buying decisions every day. Companies examined consumer's buying decisions in detail 
in order to answer the questions of what, where, how, how many, when, and why they buy (Zeithaml, 1988).

The research on the factors influencing buying decisions on products had been conducted by previous researchers. For example, Baruk and Iwanicka (2015) and Kianpou et al. (2014) examined the effect of product quality on buying decisions, while Beneke et al. (2013) examined buying decisions associated with competitive pricing. The other researchers, such as Saaksarjavi and Samiee (2011) and Cinomona (2016), examined the association of buying decision in terms of brand image. Therefore, the research was aimed to examine the effects of product quality, price, and brand image on buying decision of city cars in Indonesia.

Based on the description above, the research problems can be formulated as follows:

a. How was the effect of product quality on the buying decision of City Car in Semarang, Indonesia?

b. How was the effect of price on the buying decision of City Car in Semarang, Indonesia?

c. How was the effect of brand image on the buying decision of City Car in Semarang, Indonesia?

The benefits of the research were:

a. The research will be useful to the managements in order to formulate city car marketing programs.

b. The research is also useful for marketers in approaching the customers of city cars to be able to influence consumers in deciding to buy city cars.

\section{Buying Decision}

\section{THEORETICAL FRAMEWORK}

Buying decision is to buying the brand that consumers want the most (Chang and Wang, 2011). According to Zeithaml (1988) buying decision is the decisions individuals make to use their existing resources to consume an item. The other definition of buying decision is an integration process used to combine knowledge to evaluate two or more alternative behaviors and to choose one of them (Monroe, 2002; Zeithaml, 1988). The other description of buying decision is a decision individuals make because of stimuli from both internal and external of the individuals (Chang and Wang, 2011; Ulaga and Chacour, 2001).

Consumers make many buying decisions every day. Large companies examine consumer's buying decisions in detail to be able to answer the questions: what, where, how, how many, when, and why they buy. Marketers may study consumer's purchases to answer the questions: what, where, and how much they buy, but they learn about why consumer's buying behavior which is not very easy (Chang and Wang, 2011; Vinnikova, A., 2016). According to Monroe (2002), consumer's decision making is a process of receiving and evaluating the brand information of particular product.

There were many previous studies examining buying decisions in buying goods by associating with several factors. For example, Baruk and Iwanicka (2015) and Kianpou et al. (2014) examined consumer's buying decisions related to product quality. Beneke et al. (2013) examined buying decisions in terms of price. Cinomona (2016) examined the relation of buying decisions in terms of brand image. 


\section{Association of Product Quality with Buying Decision}

Product quality is the ability of a product to demonstrate its function (Rundh, 2009). The other definition of product quality is a product's ability to perform its functions (Albino et al., 2009). Product quality concerns general resilience of a product, reliability, precision, ease of operation, improvement, and other valuable attributes. Although some of the attributes are measurable, from marketer's point of view, product quality must be measured by buyer's perception (Deliya and Parmar, 2012). Product quality must also be determined by the way consumers perceive the product. From marketing perspective, quality is the ability of a product to satisfy the needs or desires of the consumers. The definition focuses on consumers and how consumers think that a product will meet a particular goal (Baruk, 2013).

Beyond the level of product quality, high quality also means consistent delivery of target quality level to consumers. In this sense, product quality means no damage and variety. All companies must strive for a high level of quality consistency (Rundh, 2009). Companies change product quality into a potential strategy weapon. Quality strategy is to improve quality slightly above competitors by consistently delivering better products and services to serve consumers' needs and preferences for product quality (Deliya and Parmar, 2012).

The provision of the right product at the time, place, and the way consumers want it to be a challenge. It is true, whether the product is the main service, goods, or, as usual, the combination of the two. Marketing managers should think about the whole product; available products as well as ensuring that all elements are aligned in the marketing strategy. A product is sometimes insufficient to meet the needs of the target consumers. Therefore, it is necessary to mix with other products (Wang, 2013). The companies which are not able to create new products will face the risks, such as reduced sales volume, due to the emergence of more creative competitors, the changing tastes of consumers, and the emergence of new technologies in production process (Deliya and Parmar, 2012; Wang, 2013).

There have been many studies associating product quality with customer's buying decision in terms of several different aspects (Baruk and Iwanicka, 2015; Beneke et al., 2013; Kianpou et al., 2014; Tirelli and Martínez-Ruiz, 2014). For example, Baruk and Iwanicka (2015) examined the effect of product quality on buying decision in Poland. The results proved that there is a strong effect between product quality and buying decision. Beneke et al., (2013) examined it by taking the object of household products in South Africa involving 157 respondents. The results showed a positive effect between product quality and buying decision. Furthermore, Kianpou et al. (2014) examined product quality by incorporating environmental elements in Malaysia with the result that product quality is associated with buying decision. Similarly, Tirelli and Martínez-Ruiz (2014) investigated it in Spain involving 139 international student respondents, and they found that product quality is associated with buying decision. Based on the studies, the researcher formulated the hypothesis;

H1: product quality has a positive effect on buying decision

\section{Association of Price with Buying Decision}

Price is the amount (monetary unit) and/ or other (non-monetary) aspects that contain the specific utility needed to obtain a product/ service (Huber et al., 2007). The other concept of price is the amount of money that consumers have to pay for a product (Kwon et al., 2008). Price is the only element in the marketing mix that generates revenue. Price is also the most easily customizable element of marketing mix. In addition, price also communicates the value of company's products to the market (Zeithaml, 1998).

Pricing is a critical decision that supports the success of profit and non profit organizational 
operations. Price is the only element of marketing mix that provides income for an organization. However, pricing decision is not easy to do. On the one hand, overprice may increase short-term profits, but on the other hand it will be difficult to reach by consumers and to compete with competitors (Huber et al., 2007). In certain cases, overprice may be protested by a consumer agency and even invite government intervention to lower it. In addition, large profit margins tend to attract competitors to enter the same industry. Meanwhile, when the price is too cheap, the market share will jump, but the contribution margin and net profit will be reduced. Besides, some consumers may perceive poor quality (Boksberger and Melsen, 2000).

Many studies that associated the price of goods with buying decisions were seen from various aspects. For example, the study of Beneke et al. (2013) examined the effect of prices on buying decisions on household products in South Africa. The result is that competitive price has an effect on buying decision. Similarly, Huber et al. (2007) found that there is a strong effect between price and buying decision. Therefore, the researcher made the following hypothesis:

H2: Price has significant effect on buying decision

\section{Association of Brand Image with Buying Decision}

Brand image is a perception and attitude of consumers to a brand based on what is perceived and received by consumers (Bibby, 2011). The other notion of brand image is anything related to a brand in consumer's mind or impression of a brand (Zehir et al., 2011).

Image plays an important role in influencing consumer's decision making. When a consumer does not have complete information on a product, the consumer will use brand image as the basis for selecting the product (Aghekyan-Simonian et al., 2012). Image is a consumer's perception of brand as a whole which is formed by the information received and consumer experience of the brand. What comes when consumers are asked about brand image will express his or her impression and belief on a particular brand (Zehir et al., 2012). Consumers generally have a positive perception of a pioneer brand (the first brand in a product category) even though the next brand appears. Then, there is also a positive correlation between pioneer brand image and individual's ideal image. The positive perceptions of the pioneer brand will lead to a positive buying intention (Bibby, 2011).

Many researchers had conducted the studies associating brand image with buying decisions by considering various aspects. For example, the study of Saaksarjavi and Samiee (2011) examined the relationship between brand image and buying decision which resulted in a strong association. In addition, Chinomona (2016) also strengthened the findings. Therefore, the researcher formulated the following hypothesis:

H3: Brand image has a significant effect on buying decision

\section{RESEARCH METHOD}

The study used three independent variables and one dependent variable, i.e.: product quality, price, and brand image as the independent variables and buying decision as the dependent variable. The researcher used previous studies as the discussion of the associations in the variables and made research hypothesis. Questionnaires were used to obtain primary data and to know the characteristics of the respondents who became the source of the research data. There were 120 respondents with the criteria as the owners of city cars domiciled in Semarang, Indonesia. The data obtained were analyzed using the SPSS program. 


\section{Respondent}

\section{RESULT AND DISCUSSION}

The number of the questionnaires distributed was 120. but 100 questionnaires were declared complete and could be processed. The criteria of the male respondents was 71 per cent and the female one was 29 per cent. The percentage of the respondents aged from 20 to 30 years was 31 per cent, aged from 31 to 40 years was 43 per cent, and aged 41 to 50 years was 26 per cent. The percentage of the educational level of the respondents was: 33 per cent graduated from high school, 47 per cent graduated from university, and 20 per cent graduated from postgraduate program. The proportion of the respondents working in private companies reached 42 per cent, 20 per cent as civil servants, and the remaining 38 per cent working as entrepreneurs.

\section{Data Validity and Reliability}

The result of the validity test in the research (Table 1) shows that the r-count of the questionnaires of product quality, price, brand image and buying decision is greater than the $r$ table (0.197), which means that the questionnaires of the variables are valid as the variable measurement instrument.

Table 1 : Validity Test Results

\begin{tabular}{|l|c|c|c|c|}
\hline \multicolumn{1}{|c|}{ Variable } & $\begin{array}{c}\text { Question } \\
\text { Items }\end{array}$ & $\mathrm{r}_{\text {count }}$ & $\mathrm{r}_{\text {table }}$ & Remark \\
\hline product quality & Item 1 & 0.666 & 0.197 & Valid \\
\cline { 2 - 5 } & Item 2 & 0.586 & 0.197 & Valid \\
\cline { 2 - 5 } & Item 3 & 0.677 & 0.197 & Valid \\
\hline price & Item 1 & 0.653 & 0.197 & Valid \\
\cline { 2 - 5 } & Item 2 & 0.550 & 0.197 & Valid \\
\cline { 2 - 5 } & Item 3 & 0.689 & 0.197 & Valid \\
\hline brand image & Item 1 & 0.677 & 0.197 & Valid \\
\cline { 2 - 5 } & Item 2 & 0.653 & 0.197 & Valid \\
\cline { 2 - 5 } & Item 3 & 0.621 & 0.197 & Valid \\
\hline buying decision & Item 1 & 0.632 & 0.197 & Valid \\
\cline { 2 - 5 } & Item 2 & 0.611 & 0.197 & Valid \\
\cline { 2 - 5 } & Item 3 & 0.599 & 0.197 & Valid \\
\hline
\end{tabular}

\section{Source : Processed Data}

Then, the reliability test was conducted using Cronbach Alpha $(\alpha)$ with the provision that when the variable of Cronbach Alpha $(\alpha)>0.70$, the questionnaire is reliable. The results of the reliability test result in the values of cronbach alpha of the variables of product quality, price, brand image and buying decision are greater than the standard of reliability. It shows that the questionnaires used by each research variable are proven reliable (Table 2).

Table 2 : Reliability Test Result

\begin{tabular}{|l|l|c|c|c|}
\hline \multicolumn{1}{|c|}{ Variable } & $\begin{array}{c}\text { Cronbach } \\
\text { alpha } \\
\text { Results }\end{array}$ & $\begin{array}{c}\text { Reliability } \\
\text { Standard }\end{array}$ & Remark \\
\hline product quality & & 0.789 & 0.70 & Reliabel \\
\hline price & & 0.727 & 0.70 & Reliabel \\
\hline brand image & & 0.758 & 0.70 & Reliabel \\
\hline buying decision & & 0.785 & 0.70 & Reliabel \\
\hline
\end{tabular}

Source : Processed Data 
The results of the multiple regression in the research are shown in Table 3.

Table 3. Multiple Regression Results

\begin{tabular}{|c|c|c|c|c|c|}
\hline \multirow[t]{2}{*}{ Model } & \multicolumn{2}{|c|}{$\begin{array}{c}\text { Unstandardized } \\
\text { Coefficients }\end{array}$} & \multirow{2}{*}{$\begin{array}{c}\text { Standardized } \\
\text { Coefficients } \\
\text { Beta }\end{array}$} & \multirow[t]{2}{*}{$\mathrm{t}$} & \multirow[t]{2}{*}{ Sig. } \\
\hline & B & Std. Error & & & \\
\hline (Constant) & ,118 & ,461 & & ,257 & ,799 \\
\hline $\begin{array}{l}\text { Product } \\
\text { quality }\end{array}$ & 389 & ,093 & ,372 & 4,225 & 000 \\
\hline Price & ,352 & 112 & ,332 & 3,051 & 004 \\
\hline Brand Image & 251 & 103 & ,254 & 2,282 & ,018 \\
\hline
\end{tabular}

a. Dependent Variable: Buying Decision

Source : Primary Data

Table 4. Determination Coefficient Results

Model Summaryb

\begin{tabular}{|l|r|r|r|r|}
\hline Model & \multicolumn{1}{|c|}{$\mathrm{R}$} & R Square & Adjusted R Square & \multicolumn{2}{|c|}{$\begin{array}{c}\text { Std. Error of the } \\
\text { Estimate }\end{array}$} \\
\hline 1 &, $918^{\mathrm{a}}$ &, 842 &, 835 & 1,005 \\
\hline
\end{tabular}

a. Predictors: (Constant), Brand Image, Product Quality, Price

b. Dependent Variable: Buying Decision

Source : Primary Data

\section{DISCUSSION}

The research was conducted to examine the effect of product quality, price, and brand image on the buying decision of city cars by taking the location in Semarang, Indonesia. Based on the results of the analysis using multiple regression, the fact was obtained that product quality has a positive and significant effect on buying decision. Besidesm the variables of price and brand image are also able to influence the decision in a positive direction.

The first findings of the research in the form of the significant effect of product quality on consumer decisions in a positive direction indicate that the higher the product quality offered by city cars, the higher the consumer's desire to decide to buy city car products. The effect of product quality of 0.372 on buying decision indicates that, compared with the effects of two other variable of price and brand image, in the eyes of consumers, product quality played the biggest role in influencing consumer's decision to buy city cars. Therefore, it is recommended to the managements of city car companies to always pay attention to the elements of product quality development in order than the consumers are more confident and believe to decide to buy city car products.

The research is in line with the previous studies (Baruk and Iwanicka, 2015; Beneke et al., 2013; Kianpou et al., 2014; Tirelli and Martínez-Ruiz, 2014). However, the research has differences with some other studies. Based on the results of the descriptive analysis to the results of the study, it was found that what is considered most important by consumers in assessing product quality is the strength of product interior, such as the durability of upholstery fabric. According to the respondents, the more durable the interior, the higher the quality of city car products. In other hand, what is considered the most important by the other consumers is fuel efficiency. Therefore, it is suggested to the managements of city car companies that, in addition to maintaining the fuel efficiency of the cars, they must always 
develop the quality of the interior. The trick is to make the inner parts of the vehicle durable and long lasting, such as providing a seat with durable material.

The second finding of the research was that price is able to influence consumer's buying decision in a positive and significant direction at 0.332 so that the managements of city car companies are recommended to always keep the price remains competitive to affect the increase in the number of consumers who decide to buy their cars. The research results were in line with the studies of Beneke et al. (2013) and Huber et al. (2007), but there are differences from previous research viewed from the perception of the respondents in considering the competitive prices. The study found that consumers saw that prices should still maintain the security features. In the sense, the price component must still contain the element of security for the users of city cars. Competitive prices, without leaving the security features of city car users, will be a very important thing for the respondents in deciding to buy city cars. Therefore, it is suggested to the managements of city car companies to always provide competitive prices while maintaining the safety of the users.

The third finding in the research was that the brand image was proven to have an effect on the buying decision to the brand of City Car at 0.254 . The results can be interpreted that the higher the brand image of City Car, the higher the increase of consumer's buying decision. Brand image is a perception and attitude of consumers to a brand based on what is perceived and accepted by consumers. The research results were in line with the studies of Cinomona (2016) and Saaksarjavi and Samiee (2011). Thet consumers who perceive that the products used give many advantages and benefits will make them give a good perception of the product brand and it will create a good image of the brand name. Finally, it will encourage consumers to gladly decide to buy city car products.

The values of the determination coefficient can be seen in Adjusted R Square of 0.842 (see table 4). The results indicate that product quality, price and brand image are able to explain the buying decision at $84.2 \%$ (Table 4 ).

\section{CONCLUSION AND RECOMMENDATION}

This study examined comprehensively the effect of product quality, price and brand image on the buying decision of city cars in Semarang, Indonesia. The research results surprisingly found that the variable of product quality has greater effect than the other two variables. Therefore, it is suggested to the managements of city car companies to always improve the quality of the city car products so that consumers are convinced to always decide to buy them. Improved product quality can be made by providing durable interior materials and fuel efficiency.

In relation with the other research results, price and brand image have a positive effect in determining consumers to buy city car products. It is suggested to the management of city car companies to always provide competitive price without reducing the safety means for the passengers of city cars so that it will form the image of city car brand which is safe and comfortable and ultimately impact on consumer's decision to buy city car products.

\section{Refferences}

Aghekyan-Simonian, M., Forsythe, S., Kwon, W.S. and Chattaraman, V. (2012), "The role of product brand image and online store image on perceived risks and online purchase intentions for apparel”, Journal of Retailing and Consumer Services, Vol. 19 No. 3, pp. 325-331.

Albino, V., Balice, A. and Dangelico, R.M. (2009), "Environmental strategies and green product development: an overview on sustainability-driven companies", Journal of Business Strategy and the Environment, Vol. 18 No. 2, pp. 83-96. 
Amron, A. (2017), "Marketing Challenge of Import Insurance Product in Indonesia", Advance Science Letters, Vol. 3 No. No. 8, pp. 7243-7245.

Baruk, A. (2013). “Offerers' Relations with Customers. Marketing Holistic Approach and Marketing Practice, Lambert Academic Publishing, Saarbrücken.

Baruk, A.I. and Iwanicka, A. (2015). Polish final purchasers' expectations towards the features of dairy product packaging in the context of buying decisions. British Food Journal, Vol. 117 Issue: 1, pp.178-194.

Beneke, J., Flynn, R., Greig, T. and Mukaiwa, M. (2013). The influence of perceived product quality, relative price and risk on customer value and willingness to buy: a study of private label merchandise. Journal of Product \& Brand Management, Vol. 22 No. 3, pp. 218228.

Bibby, D.N. (2011), "Sponsorship portfolio as brand image creation strategies: A commentary essay", Journal of Business Research, Vol. 64, pp. 628-630.

Boksberger, P.E. and Melsen, L. (2011), "Perceived value: a critical examination of definitions, concepts and measures for the service industry", Journal of Services Marketing, Vol. 25 No. 3, pp. 229-240.

Chang, H.H. and Wang, H.W. (2011), "The moderating effect of customer perceived value on online shopping behaviour", Online Information Review, Vol. 35 No. 3, pp. 333-359.

Chinomona, R. (2016), "Brand communication, brand image and brand trust as antecedents of brand loyalty in Gauteng Province of South Africa", African Journal of Economic and Management Studies, Vol. 7 No. 1.

Deliya, M.M. and Parmar, B.J. (2012), "Role of packaging on consumer buying behavior", Global Journal of Management and Business Research, Vol. 12 No. 10, pp. 48-68.

Huber, F., Herrmann, A. and Henneberg, S.C. (2007), "Measuring customer value and satisfaction in services transactions, scale development, validation and crosscultural comparison", International Journal of Consumer Studies, Vol. 31 No. 6, pp. 554-564.

Kianpou, K., Jusoh, A., and Asghari, M. (2014),"Environmentally friendly as a new dimension of product quality", International Journal of Quality \& Reliability Management, Vol. 31 Iss 5, pp. 547 - 565

Kwon, K.N., Lee, M. and Kwon, Y.J. (2008), "The effect of perceived product characteristics on private brand purchases", Journal of Consumer Marketing, Vol. 25 No. 2, pp. 105-114.

Monroe, K.B. (2002), Pricing: Making Profitable Decisions, 3rd ed., McGraw-Hill, New York, NY.

Rundh, B. (2009), “Packaging design: creating competitive advantage with product packaging”, British Food Journal, Vol. 111 No. 9, pp. 988-1002.

Saaksjarvi, M. and Samiee, S. (2011), "Relationships among Brand Identity, Brand Image and Brand Preference: Differences between Cyber and Extension Retail Brands over Time", Journal of Interactive Marketing, Vol. 25 No. 3, pp. 169-177.

Seizure, 2016, Why choice City Car? http://seizurechicken.com/mengapa-memilih-city-car/ (accesed 11 November 2016).

Tirelli, C. and Martínez-Ruiz, M.P. (2014), "Influences of product attributes on sojourners' food purchase decisions", British Food Journal, Vol. 116 Iss 2 pp. 251 - 271.

Topbrand, 2016, Top Brand Award, http://www.topbrand-award.com/top-brand-survey/surveyresult/top_brand_index_2016_fase_2 (accesed 04 January 2017).

Ulaga, W. and Chacour, S. (2001), "Measuring customerperceived value in business markets", Industrial Marketing Management, Vol. 30 No. 6, pp. 525-540.

Vinnikova, A. (2016), "A case of hedonic perception of foreigners towards Chinese culture-specific odors from scent marketing perspective", Archives of Business Research, Vol.4, No.3, pp. 21-44.

Wang, E.S.T. (2013), "The influence of visual packaging design on perceived food product quality, value, and brand preference", International Journal of Retail \& Distribution Management, Vol. 41 No. 10, pp. 805-816.

Zehir, C., Sahin, A., Kitapci, H. and Ozsahin, M. (2011), "The Effects Of Brand Communication And Service Quality In Building Brand Loyalty Through Brand Trust; The Empirical Research On Global Brands", The 7th International Strategic Management Conference, Paris-France.

Zeithaml, V.A. (1988), “Consumer perceptions of price, quality, and value: a means-end model and synthesis of evidence", Journal of Marketing, Vol. 52, July, pp. 2-22. 